\title{
MACARANGA LEAVE CAPSULE AS ON DYSMENORRHEA AS A COMPLEMENTARY THERAPY
}

\author{
Candra Kusuma Negara, Sri Erliani, Kristiani \\ Universitas Cahaya Bangsa, Banjarmasin
}

\begin{abstract}
Background: Dysmenorrhea is a gynaecological complaint due to an imbalance of the hormone progesterone in the blood, which causes pain. Dysmenorrhea can be treated with nonpharmacological methods, namely by herbal therapy of macaranga (Macaranga triloba) leaves because macaranga leaves contain anti-oxidants which have the effect of reducing dysmenorrhea pain. This study aimed to examine the effect of macaranga leave capsule as on dysmenorrhea as a complementary therapy

Subjects and Method: This was an experimental study with pre and posttest study without a control group design. Total of 60 female students were taken by accidental sampling. The dependent variable was dysmenorrhea. The independent variable was macaranga leave capsule. The study instrument used was Sclae Numeric Rating Scale by measuring the dysmenorrhea pain scale before and after being given mcaranga leaf capsule therapy. After 15 minutes, the dysmenorrhea pain scale was measured again. The data were analyzed using Wilcoxon test.

Results: The results showed that on the first and second day, 57 respondents experienced a decrease in dysmenorrhea pain and 3 respondents did not experience a decrease in dysmenorrhea pain, and it was statistically significant $(\mathrm{p}<0.001)$.

Conclusion: Macaranga leave capsule can decrease the pain of dysmenorrhea among female students.
\end{abstract}

Keywords: macaranga, dysmenorrhea, female student

\section{Correspondence:}

Candra Kusuma Negara. Universitas Cahaya Bangsa. Jl. A.yani ST.KM 17 Peat, Banjarmasin, South Kalimantan. Email: Candra14780@yahoo.com. Mobile: o85252852701 